\section{Effect of Topical 2\% Eucalyptus Extract on 5-FU-Induced Oral Mucositis in Male Golden Hamsters}

Nader Tanideh ${ }^{1}$, Arash Badie ${ }^{\mathbb{D}}$, Raha Habibagahi ${ }^{3}$, Omid koohiHosseinabadi $^{4}$, Sara Haghnegahdar ${ }^{5}$ (D), Azadeh Andisheh-Tadbir 6 (D)

\author{
'Stem Cells Technology \\ Research Center, Pharmacology \\ Department, Shiraz Medical \\ School, Shiraz University of \\ Medical Sciences, Shiraz, Iran \\ ${ }^{2}$ Oral and Dental Disease \\ Research Center, Shiraz Dental \\ School, Shiraz University of \\ Medical Sciences, Shiraz, Iran \\ ${ }^{3}$ Orthodontic Research Center, school \\ of dentistry, Shiraz University of \\ Medical Sciences, Shiraz, Iran \\ ${ }^{4}$ Laboratory Animals Center, \\ Shiraz University of Medical \\ Sciences, Shiraz, Iran \\ ${ }^{5}$ Department of Oral Medicine \\ and Diagnosis, School of \\ Dentistry, Shiraz University of \\ Medical Sciences, Shiraz, Iran \\ ${ }^{6}$ Department of Oral and \\ Maxillofacial Pathology, School \\ of Dentistry, Shiraz University of \\ Medical Sciences, Shiraz, Iran
}

Correspondence: Raha-Habibagahi, Ghasrodasht St, Dental School of

Shiraz University of Medical Sciences.

Shiraz, Iran. Tel: +989178118417.

e-mail: raha2979@yahoo.com

Key Words: oral mucositis, hamster, eucalyptus, gel, stereology, histology.

\section{Introduction}

Head and neck cancer is the sixth leading cancer by incidence worldwide and eighth by death (1). Surgical resection, radiation, and chemotherapy are the mainstays of treatment for most head and neck cancers and remain the standard of care in most cases. Oral mucositis (OM) is a frequent complication of treatments with radiotherapy or chemotherapy. OM is a painful, erythematous, inflamed, and ulcerated mucosal disease that is covered by a yellowwhite fibrin clot pseudomembrane. Pain and loss of taste perception can cause difficulty in swallowing, speaking, and receiving nutrition, which can lead to weakness, low quality of life, and higher treatment costs (2).

After exposure to neoplastic treatments, there is DNA and non-DNA damage in the oral mucosa. Cascade production of free radicals, which cause oxidative stress and reactive oxygen species, is the initial oral mucosal layer and blood vessel injuries. The severity of oral mucositis correlates with the intensity of pro-inflammatory cytokine production, such as tumor necrosis factor (TNF), interleukin-6 (IL-6), and interleukin-1 beta (IL-1 $\beta$ ). Apoptotic changes appear in the form of mucositis in early radiotherapy or chemotherapy (3).

Improvements in the diagnosis and targeted treatment increase the survival rate and convenience of patients (4).
Managing these complications can be done through the following steps: maintaining good oral hygiene, reducing the radiation dose, optimizing pain control with antiinflammatory drugs, enhancing growth factors, such as palifermin, natural agents, cryotherapy, and low-level laser dose therapy (LLLT) $(5,6)$.

Modern medicine recognizes herbalism derived from natural sources as an alternative medicine, phytotherapy in many diseases and a preventive method against complications that result in chemotherapy-induced OM. Calendula officinalis (C. officinalis) (7), Hypericum perforatum (8), Pistacia atlantica and Zizyphus jujuba have been used to accelerate the healing of $\operatorname{OM}(9,10)$.

Eucalyptus is comprised of more than 100 different natural compounds, such as cineole (eucalyptol), pinene (alpha, $\alpha)$, limonene (delta, $\delta)$, terpineol $(a l p h a, \alpha)$, cymene (para), eudesmol, and aromadendrene (11).

The hydroalcoholic extract of eucalyptus contains multiple medicinal properties, such as being antibacterial, antiviral, antifungal, antiinflammatory, analgesic, and antioxidant. The medicinal eucalyptus oil is probably the most powerful antiseptic of its class, especially when it is old as ozone is formed in it on exposure to the air. It has distinct disinfectant action, destroying the lower forms 
of life $(12,13)$.

Considering the effect of multiple properties of eucalyptus and the insufficient data about its efficacy on $\mathrm{OM}$, the present study was conducted to evaluate the healing effects of $2 \%$ eucalyptus extract gel on $\mathrm{OM}$ induced by the chemotherapeutic agent 5-FU in male golden hamsters based on clinical, histopathologic, stereological, and tissue antioxidant index evaluations.

\section{Material and Methods}

Ethical considerations were confirmed by the Animal Care Committee of Shiraz University of Medical Sciences (NO: 8794115). The experiments were carried out in accordance with the guidelines laid down by the National Institute of Health $(\mathrm{NIH})$ regarding the care and use of animals for experimental procedures.

\section{Animals and Housing}

Thirty male golden hamsters (100 to 120 g, 6-8 weeks old) were taken and prepared from the laboratory animal center of Shiraz University of Medical Sciences. Animals were housed in standard cages under equal light and dark periods of $12 \mathrm{~h}$ (lights on at 8:00 pm), with an ambient temperature of $22 \pm 2{ }^{\circ} \mathrm{C}$ and $55 \%$ relative humidity. Hamsters were given a 5 -day acclimation period with access to normal chow and free water before the experiment.

\section{C. officinalis Extract Gel Formulation}

A gel-forming agent was prepared with $2 \%$ sodium carboxymethyl cellulose ( $\mathrm{NaCMC}$ ) dispersed in $5 \%$ glycerol under continuous stirring with a suitable drive mixer at 500 rpm. Then, adequate amounts of $C$. officinalis extract $(0.5 \%$ and $10 \%$ ) were added to sufficient amounts of deionized water. The mixtures were added to the $\mathrm{NaCMC}$ with glycerol gradually. The resultant gels were homogenized for $30 \mathrm{~min}$ and each formulation was filled in an aluminum tube. They were then sealed, and each formulation was used as required during the 1 -month formulation.

\section{Preparation of Eucalyptus Hydroalcoholic Extract}

The leaves of the eucalyptus were dried at room temperature and powdered in a grinder. Aqueous ethanol (75\%) was added to the powdered materials (500 g) and stirred for $1 \mathrm{~h}$. The mixture was kept at room temperature for $48 \mathrm{~h}$. Following filtration, ethanol was evaporated under reduced pressure at $40{ }^{\circ} \mathrm{C}$. The remained water extract was dried at the oven temperature of $50^{\circ} \mathrm{C}$. Finally, the $2 \%$ eucalyptus hydroalcoholic extract was prepared in a pharmacy laboratory.

\section{Chemotherapy-Induced Oral Mucositis}

Thirty adult male golden hamsters were randomly allocated into 3 equal groups. All animals received three intraperitoneal injections of 5-FU on days 0,5 , and 10 at a dose of $60 \mathrm{mg} / \mathrm{kg}$ with insulin needles, following the protocol proposed by Sonis et al. (14). To mimic the clinical effects of the chronic irritation, the cheek pouch mucosa was scratched superficially with the tip of an 18-gauge sterile needle after the area had been anesthetized. Two horizontal linear scratches were made across the everted cheek pouch once daily on days 3 and 4 . The treatment started on day 12 . The control group did not receive any treatment; the calendula group was treated with a Calendula officinalis extract gel; and the eucalyptus group was treated with a 2\% eucalyptus extract gel) on the cheek pouch mucosa of both sides once a day (morning) and the affected area was completely covered. To make sure that the drug was not swallowed, animals were not allowed to eat or drink for $45 \mathrm{~min}$ after the administration of the drug. Five hamsters from each group were randomly selected for euthanasia on days 14 and 17. At the time of euthanasia, they were anesthetized with $100 \mathrm{mg} / \mathrm{kg}$ ketamine $10 \%$ (Alfasan, Netherlands) and $10 \mathrm{mg} / \mathrm{kg}$ xylazine 2\% (Alfasan, Netherlands).

\section{Histopathological Study}

Both side cheek pouches tissue of hamsters in all groups were harvested on days 14 and 17. Tissues obtained from the right side pouch were proceeded and stained with hematoxylin-eosin and examined by light microscopy $(x 40)(15)$. The specimens were examined histopathologically and received scores of 0 to 3 , as described in Lima's method (16):

- Score 0, normal epithelium and connective tissue without vasodilatation; absent or mild inflammatory infiltrate; absence of bleeding, ulcers, and abscesses;

- Score 1, mild vascular hyperemia; areas of reepithelialization; mild inflammatory infiltrate with a prevalence of mononuclear cells; no hemorrhagic areas, ulcerations or abscesses;

- Score 2, moderate vascular redness; areas of epithelial degeneration; inflammatory infiltration with a prevalence of neutrophils; hemorrhagic areas, edema, and occasional ulcerations; absence of abscesses;

- Score 3, severe hyperemia and vascular vasodilatation; inflammatory infiltration.

\section{Measurement of Malondialdehyde (MDA)}

Tissues obtained from the left side pouch were stored under liquid nitrogen until measurement. Tissue malondialdehyde (MDA) assessment was performed via the measurement of thiobarbituric acid reactive substances (TBARS) in PBS tissue homogenate (17) because MDA is one of the end-products of lipid peroxidation (LPO), measured 
by estimating the MDA levels (18).

\section{Myeloperoxidase (MPO) Assay}

The MPO activity can be measured in the tissues by using hydrogen peroxide and odianisidine dihydrochloride as substrates (19). Briefly, the cheek pouch tissues which were collected on days 14 and 17 were weighed and homogenized in a solution, containing $0.5 \%(\mathrm{w} / \mathrm{v})$ hexadecyltrimethylammonium bromide dissolved in $10 \mathrm{mmol} / \mathrm{L}$ potassium phosphate buffer $(\mathrm{pH} 7.4)$, and centrifuged for $30 \mathrm{~min}$ at $20,000 \mathrm{~g}$ at $4{ }^{\circ} \mathrm{C}$. An aliquot of supernatant was then removed and added to a reaction mixture, containing $1.6 \mathrm{mmol} / \mathrm{L}$ tetramethylbenzidine and $0.1 \mathrm{mmol} / \mathrm{L}$ hydrogen peroxide $\left(\mathrm{H}_{2} \mathrm{O}_{2}\right)$. The rate of change in the absorbance was measured spectrophotometrically at $650 \mathrm{~nm}$. MPO activity was defined as the quantity of enzyme required to degrade $1 \mathrm{mmol}$ of $\mathrm{H}_{2} \mathrm{O}_{2}$ at $37^{\circ} \mathrm{C}$ and expressed in $\mathrm{U} / \mathrm{g}$ wet tissue.

\section{Tissue Glutathione (GSH) Measurewments}

The assay mixture consisted of $2.0 \mathrm{ml}$ of $75 \mathrm{mmol}$ phosphate buffer (pH 7.0), $50 \mu \mathrm{L}$ of $60 \mathrm{mmol} \mathrm{GSH}, 0.1 \mathrm{~mL}$ of $30 \mathrm{U} / \mathrm{ml}$ GSH reductase, $0.1 \mathrm{ml}$ of $15 \mathrm{mmol}$ disodium of change in the absorbance due to the conversion of NADPH to nicotinamide adenine dinucleotide phosphate (NADP) was recorded spectrophotometrically at $340 \mathrm{~nm}$ for $3 \mathrm{~min}$. GSH activity was expressed as micromoles of NADPH oxidized to NADP $\mathrm{min}^{-1} \mathrm{mg}^{-1}$ protein using the extinction coefficient $\left(6.22 \mathrm{mM}^{-1} \mathrm{~cm}^{-1}\right)$ for NADPH 24 .

\section{Stereological Study}

The oral mucosa was sectioned axially and ten 4- $\mu \mathrm{m}-$ thick and ten $26-\mu \mathrm{m}$-thick sections per animal were sampled in a systematic uniform random pattern. The sections were stained with both Heidenhain's AZAN trichrome stain and hematoxylin-eosin. The microscopic analyses of the oral mucosa were performed using a video-microscopy system made up of a microscope (E-200; Nikon ${ }^{\text {TM }}$; Tokyo, Japan), a video camera, and a flat monitor. Four $\mu \mathrm{m}$ sections were used to estimate the volume density of the oral epithelium, connective tissue, and collagen bundles using the pointcounting method. Briefly, a point grid was overlaid on the monitor and the subsequent formula was used to estimate the volume density $(\mathrm{W})$ of the favored structure:

$\mathrm{W}=\Sigma \mathrm{P}$ (structure) $/ \Sigma \mathrm{P}$ (reference)

where $\Sigma \mathrm{P}$ (structure) and $\Sigma \mathrm{P}$ (reference) are the total points hitting the favored structure and reference tissue.

To estimate the mean height of the layers (epithelium, whole mucosa), the isotropic lines were imposed on the images of the 4- $\mu \mathrm{m}$-thick sections of the mucosa. The thickness was measured vertically at the meeting points of the lines and mucosa.

The numerical density (Nv: number of the cells per unit volume of the connective tissue) of the fibroblasts was approximated by employing the $26-\mu m$-thick sections. Also, the "optical disector" method (Fig. 1) and the following formula were applied:

$$
N v(\text { cells/connectivetissue })=\frac{\sum Q^{-}}{\sum P \times\left(\frac{a}{f}\right) \times h} \times \frac{t}{B A}
$$

where " $\Sigma Q_{-}$" is the number of the fibroblast nuclei coming into focus during scanning " $h " ; " ~ \Sigma P$ " is the total count of the unbiased counting frame in all fields; "a/f" is the frame area; " $h$ " is the height of the disector; " $t$ " is the mean section thickness; and "BA" is the block advance of the microtome set at $26 \mu \mathrm{m}$. "t" and z-axis movement (h) of the microscope stage were measured using a microcator
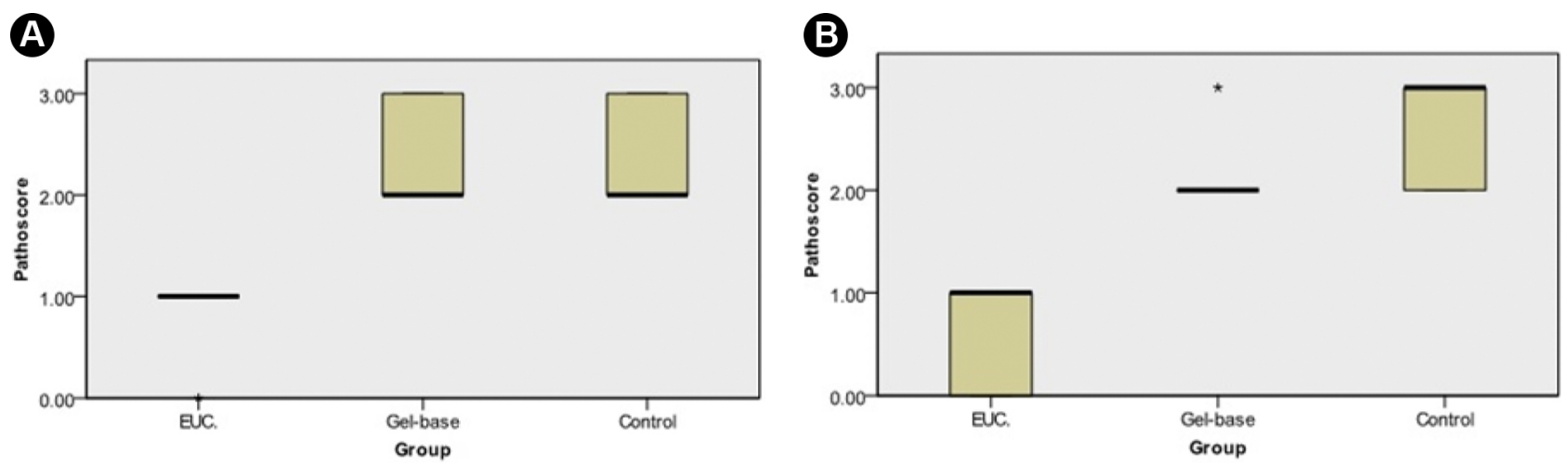

Figure 1. A comparison between three different groups in two days of sampling. A: Histopathological score on the 14th day; B: Histopathological score on the 17th day. 
(MT 25, Heidenhain, Traunreut, Germany).

\section{Statistical Analysis}

All statistical analyses were carried out using SPSS ${ }^{\circledR}$ statistical software, version 20.0 (SPSS Inc., Chicago, IL, USA) for Windows ${ }^{\circledR}$. Quantitative and qualitative variables are described as the mean \pm standard deviation (SD). One-sample Kolmogorov-Smirnov test was used to test the normality of distribution of the collected data. An independent-samples Kruskal-Wallis Test was used to assess significant differences between the study groups with regard to the MDA level, GSH and MPO activities, and the pathologic score. Additionally, the independent-samples T-Test was used to compare the treated group on different days. Differences were considered significant when $p<0.05$.

\section{Results}

\section{Histopathological Assessment}

Histopathological changes according to the determined scores showed that the peak inflammation of OM happened on the 12th day (based on clinical evaluation), and the treatment was initiated on this day. There was a significant histopathological difference between the treated group and the control group. No difference was observed between the control group and the gel-based group on different days. Over the whole treatment period, the histopathological scores in the treated group were lower than those in the gel-based and control groups, indicating less severe inflammation in the eucalyptus-treated group (Fig. 1).

Epithelialization and wound healing were detected in the eucalyptus-treated group whereas extensive infiltration of inflammatory cells, hemorrhage, and ulcers were observed in the control and gel-based groups. On days 14 and 17, the histopathological scores for the treated group were lower than those in the gel-based group

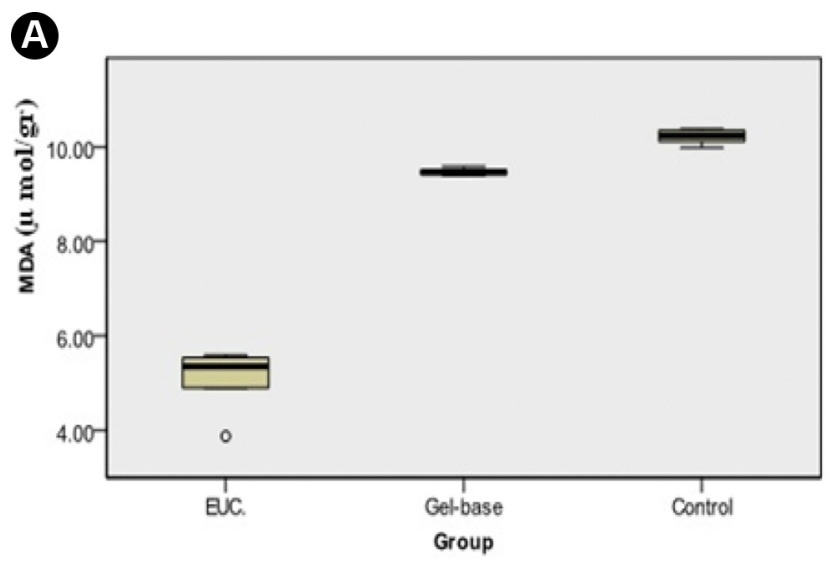

( $p=0.005, p=0.016$, respectively). Also on days 14 and 17, the histopathological scores for the treated group were lower than those of the control group $(p=0.005, p=0.002$, respectively).

\section{Tissue MDA Level Assessment}

The measurement of tissue MDA concentrations showed no differences in the MDA concentrations between the gel-based and control groups on different days. The MDA concentration in the control and gel-based groups was higher than that in the treated group on the $14^{\text {th }}$ and $17^{\text {th }}$ day ( $p=0.002$ in both days), indicating more oxidative stress in the gel-based and control groups. On days 14 and 17, the MDA concentration for the treated group was lower than that of the gel-based group ( $p=0.009$ and $p=<0.001$, respectively). Nevertheless, the MDA concentration in the Eucalyptus-treated group on the $14^{\text {th }}$ and $17^{\text {th }}$ day was significantly lower than that of the control group ( $p=0.001$ and $p=0.009$, respectively). The difference between the treated groups was significant $(p=0.002)$. Tissue MDA concentrations on the $14^{\text {th }}$ day $(5.05 \pm 0.71)$ were higher than those on the $17^{\text {th }}$ day $(2.06 \pm 0.27)$ (Fig. 2).

\section{Tissue MPO Level Assessment}

Tissue MPO activity in the study groups showed significant differences in the MPO activity between all three groups on the 14 th and 17 th day $(p=0.008,17=0.005$, respectively). On the 14th day, there was a significant difference between the treated group, on one hand, and the control $(p=0.004)$ and gel-based $(p=0.016)$ groups, on the other hand. On the 17th day, significant differences were detected between the treated group, on the one hand, and the control $(p=0.001)$ and gel-based $(p=0.033)$ groups, on the other hand. The difference between the Eucalyptus-treated groups was significant $(p=<0.001)$. The

Figure 2. A comparison of malondialdehyde (MDA) concentrations between three different groups in two days of sampling. A: MDA concentration on the 14th day; B; MDA concentration on the 17th day.

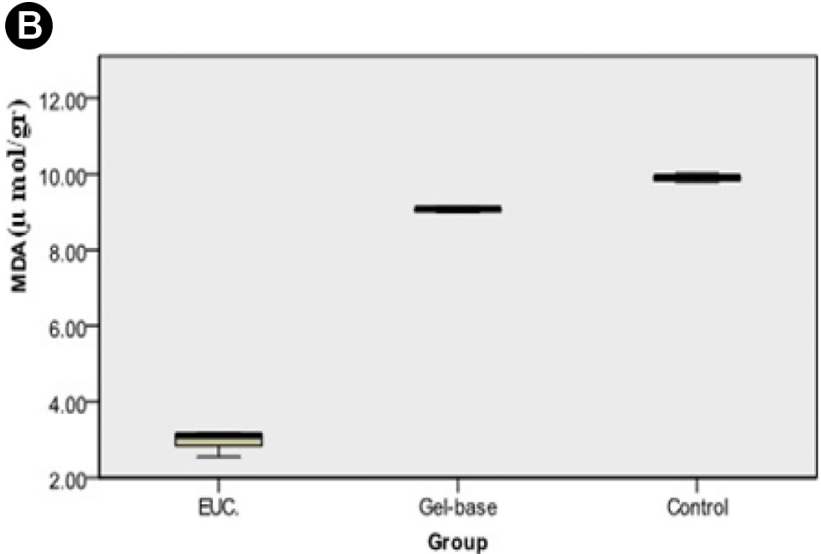


tissue MPO activity on the 14 th day $(126 \pm 5.91)$ was lower than that on the 17 th day $(224.6 \pm 8.61)$.

\section{Tissue GSH Level Assessment}

The difference between the GSH level in all the study groups was significant ( $p=0.005$ and $p=0.002$, respectively). GSH had more activity in the treated group than in the control $(p=0.001)$ and gel-based $(p=0.034)$ groups on the 14th day. Respectively, on the 17th day, significant differences were detected between the treated group, on the one hand, and the control $(p=<0.001)$ and gel-based $(p=0.009)$ groups, on the other hand. There were no differences between the tissue GSH level in the control and gel-based groups on the14th and 17th day. The difference between the treated groups was significant $(p=<0.001)$. Tissue GSH level on the 14 th day $(1.12 \pm 0.04)$ was lower than that on the 17th day (1.76 \pm 0.08$)$ (Fig. 3).

\section{Stereology Assessment}

The mean of the epithelium thickness showed a 50\% increase in the eucalyptus 14-day group in comparison to that of the control and gel-based groups. The epithelium thickness indicated a $61 \%$ increase in the eucalyptus $17-$ $\vec{s}$ day group in comparison to that of other groups $(p<0.01$, Fig. 4A, Fig. 5).

The total thickness of the mucosa and submucosa showed a $60 \%$ increase on average in the thickness of both layers in the Eucalyptus-treated (14 or 17 days) hamsters in comparison to that of the animals in the control and gel-based groups ( $p<0.01$, Fig. $4 B)$.

The mean volume density of the collagen showed an increase of $35 \%$ on average in the eucalyptus (14 or 17 days) group in comparison to that of the control and gelbased groups ( $p<0.01$, Fig. $4 \mathrm{C}$ ).

The numerical density of the fibroblast significantly increased by $88 \%$ on average in the Eucalyptus (14 or 17 days) group in comparison to that of the control and gel- based groups ( $p<0.01)$ (Figs. 4D).

\section{Discussion}

This study was conducted to evaluate the histopathological, stereological, and antioxidant markers of 2\% eucalyptus on induced oral mucositis in male golden hamsters. A large and increasing number of patients are consuming medical herbs without accurate information about their safety and efficacy and seek the advice of their physicians regarding their use. The findings of this study provide physicians with some convincing data which encourage them to help their patients make wise decisions about the use of the medical herbs. NSAIDs are commonly used for inflammatory diseases.

Some herbal medicines with no side effects are used for the treatment of OM in animal models. Tanideh et al. (7) showed that the accelerated healing effect, antitoxicity, and antimicrobial properties of $C$. officinalis may make it an appropriate drug for the treatment of OM. Showraki et al. (20) demonstrated that daily application of olive leaf extract ointment had a healing effect on 5-fluorouracil induced OM in hamsters. Moreover, the reported beneficial effects of olive leaf extract on $\mathrm{OM}$ might be due to its antioxidant and anti-inflammatory properties. Mardani et al. (21), evaluated the effects of Carum Carvi L hydroalcoholic extract on oral mucositis and showed that the use of CHE in topical form may be associated with reduced intensity of OM. This may be due to its appropriate antibacterial activity and the terpinene contents in it. Koohi-Hosseinabadi et al. (22) also investigated the healing effects of Elaeagnus angustifolia in 5-fluorouracil (5-FU)-induced OM in golden hamsters. They showed that the hydroalcoholic extract of E. angustifolia can be used as an appropriate drug for the treatment of oral mucositis based on the extract healing stimulatory and anti-inflammatory properties. Eucalyptus has multiple medicinal properties, such as being antibacterial, antiviral, antifungal, anti-inflammatory, analgesic, and antioxidant.
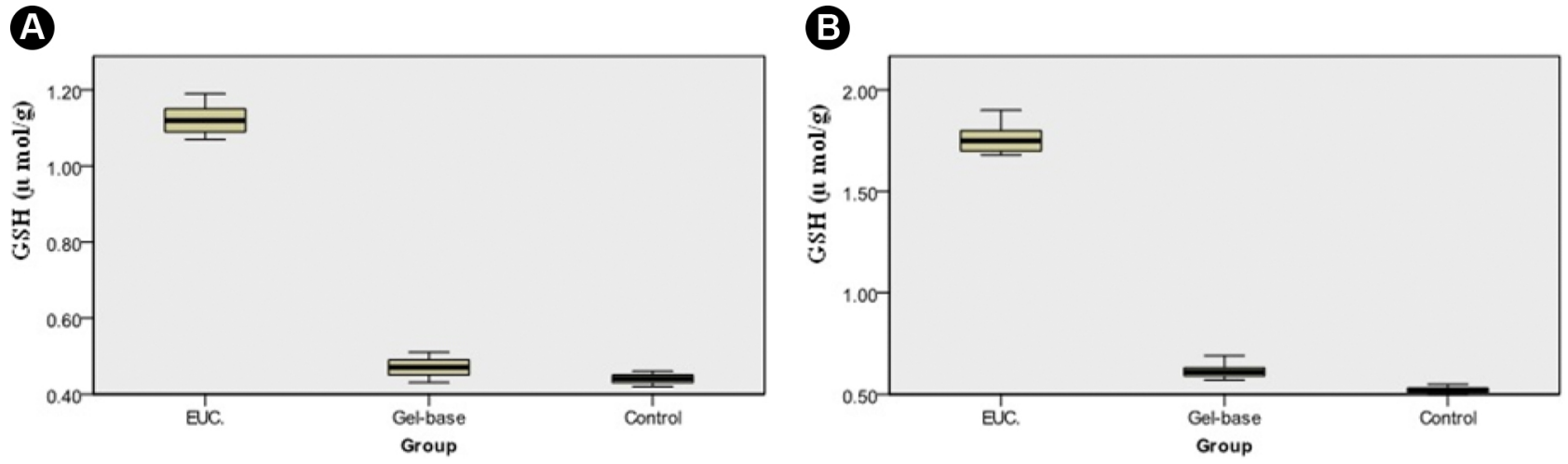

Figure 3. A comparison of glutathione (GSH) activity between three different groups in two days of sampling. A: GSH activity on the 14th day; B: GSH activity on the 17th day. 
Eucalyptus can reduce the inflammation process due to its main components, including eucalyptol, thymol, gallic acid, caffeic acid, quercetin, and rutin (12). Sodium carboxymethyl cellulose ( $\mathrm{NaCMC}$ ) is a bioadhesive polymer used for delivery of drugs to the oral cavity, including eucalyptus extract (13).

Darshan et al. (23) demonstrated that the presence of tannins (gallic acid) had astringent action and disinfectant and anti-inflammatory effects. Eucalyptus has been used as a traditional medicine for the treatment of different diseases. The consumption of eucalyptol as medicine is safe and it can be taken orally up to 12 weeks. It is able to eliminate the microorganism and fungi. The main components which give it such properties are cineole, eucalyptol, tannin, linalool, chlorogenic acid, thymol, limonene, and pinene. The monoterpenoid components present in the essential oils from Eucalyptus are commercially available for the treatment of flu, respiratory infections, and inflammations disorders (24).

Our findings derived from the histopathologic assessment showed that the $2 \%$ eucalyptus had lower microscopic scores compared to other groups on the 14th and 17th day. The reduction in the histopathologic scores indicates the healing process of this therapeutic agent. The
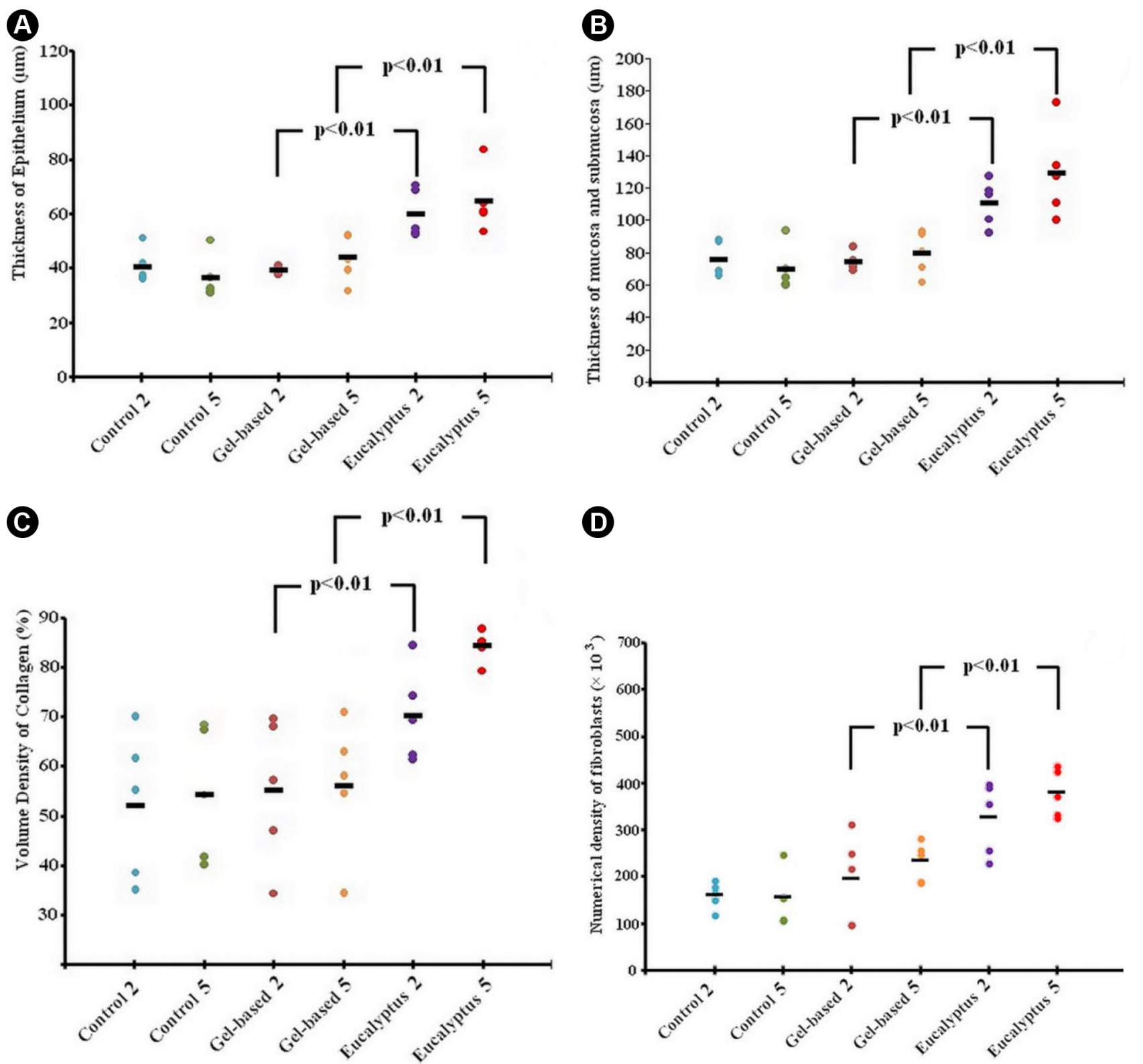

(D)

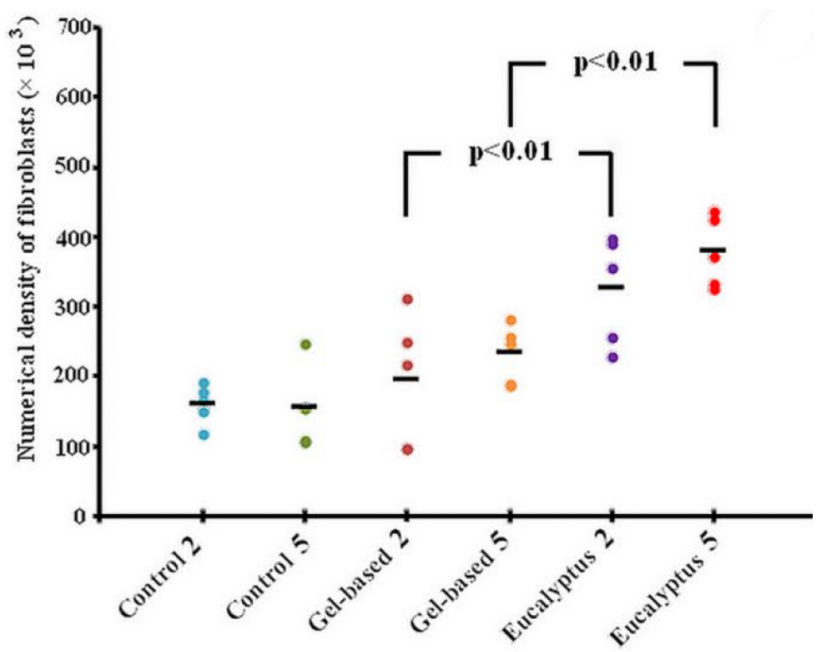

Figure 4. The plots of the quantitative parameters of the oral mucosa in the chemotherapy-exposed hamsters which received no treatment (control), gel-based agent, and eucalyptus extract gel for 2 or 5 days. A: Thickness of Epithelium $(\mu \mathrm{m})$; B: Thickness of mucosa and submucosa $(\mu \mathrm{m})$; C: Volume Density of Collagen (\%); D. Numerical density of fibroblast $\left(\times 1000 / \mathrm{mm}^{3}\right)$. The significant differences between the gel-based and the eucalyptus group are shown on the plots. 
overall histopathologic changes were expected as some previous studies had reported the presence of quercetin in calendula officinalis. Our findings are in agreement with those of Hukkeri et al. (25), who investigated the wound healing property of Eucalyptus globulus leaf extract.

Oxidative stress from free radicals is involved in the pathophysiology of many inflammatory diseases. Our data showed that eucalyptus as a protective rule of antioxidative enzymes included MDA, MPO, and GSH in the pathogenesis of OM. In this study, we observed that the eucalyptus group could decrease MDA concentration and elevate MPO and
GSH activity compared to other groups.

The stereological results of our study indicated that the hydroalcoholic extract of eucalyptus could promote the epithelium and connective tissue regeneration in chemotherapy-induced $\mathrm{OM}$ groups compared to other groups. These findings were in agreement with those obtained in the previous studies, demonstrating that eucalyptus citriodoral was able to reduce the epithelialization period (15).

Based on our findings, the numeric density of the fibroblast increased in the Eucalyptus-treated group in
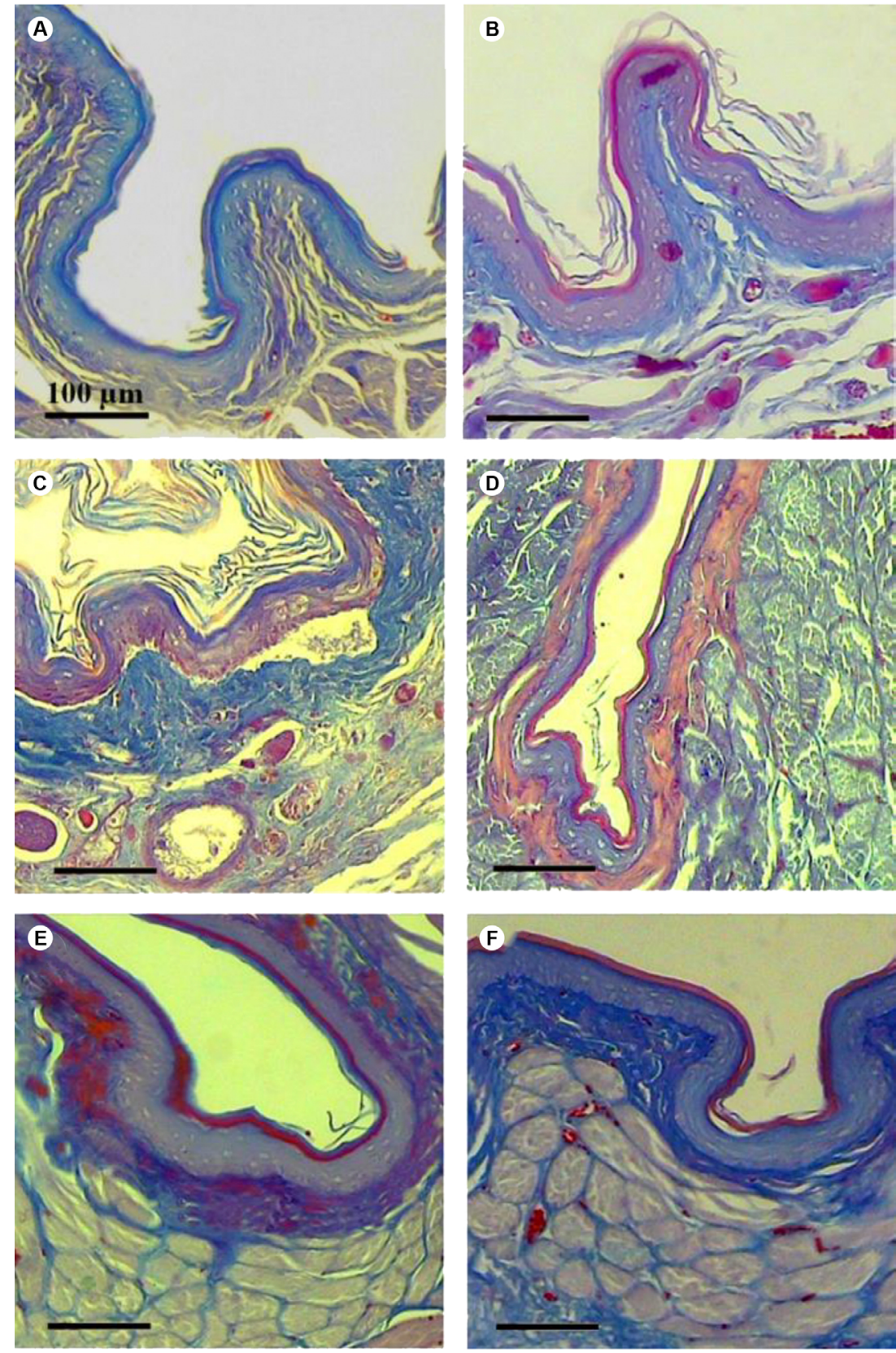

Figure 5. The micrograph of the thickness of the epithelium and connective tissue of the mucosa of different groups. A: Control group on the 14th day; B: Control group on the 17th day; C: Gel-based group on the 14th day; D: Gel-based group on the 17th day; E: Eucalyptus-treated group on the 14th day; F): Eucalyptus-treated group on the 17th day. 
comparison to that of the control and gel-based groups. These findings are in line with those of the study conducted to investigate the wound healing potential of leaves of eucalyptus citriodoral in rats, the results of which showed that Tannins could promote wound healing through several cellular mechanisms, including scavenging of free radicals and reactive oxygen species, promoting the contraction of the wound, and increasing the formation of capillary vessels and fibroblasts (26). The re-epithelialization of wound involves the migration of keratinocytes from the edges of the wound. The role of fibroblasts in the re-epithelialization process and the reconstitution of the dermal-epidermal junction has been documented (27).

Collagen is the main structural protein in various connective tissues in animals. The fibroblast is the most common cell that creates collagen. Since eucalyptus had a promotive effect on fibroblast, an increase in collagen, as its product, is expected. The results of the current study confirmed an increase of 35\% in the treated groups compared to other groups. Previous studies have claimed that the synthesis of collagen increases in the eucalyptustreated groups (15).

Compared with the control and gel-based groups, the Eucalyptus group increased re-epithelialization. These data indicate that Eucalyptus can accelerate wound healing in OM through anti-inflammatory pathways (28). This finding and the established safety profile of Eucalyptus provide a rationale for studying the topical application of this agent in a clinical setting.

Based on the results of this study, eucalyptus might be effective in OM treatment. However, further studies must focus on its active anti-inflammatory and antioxidative
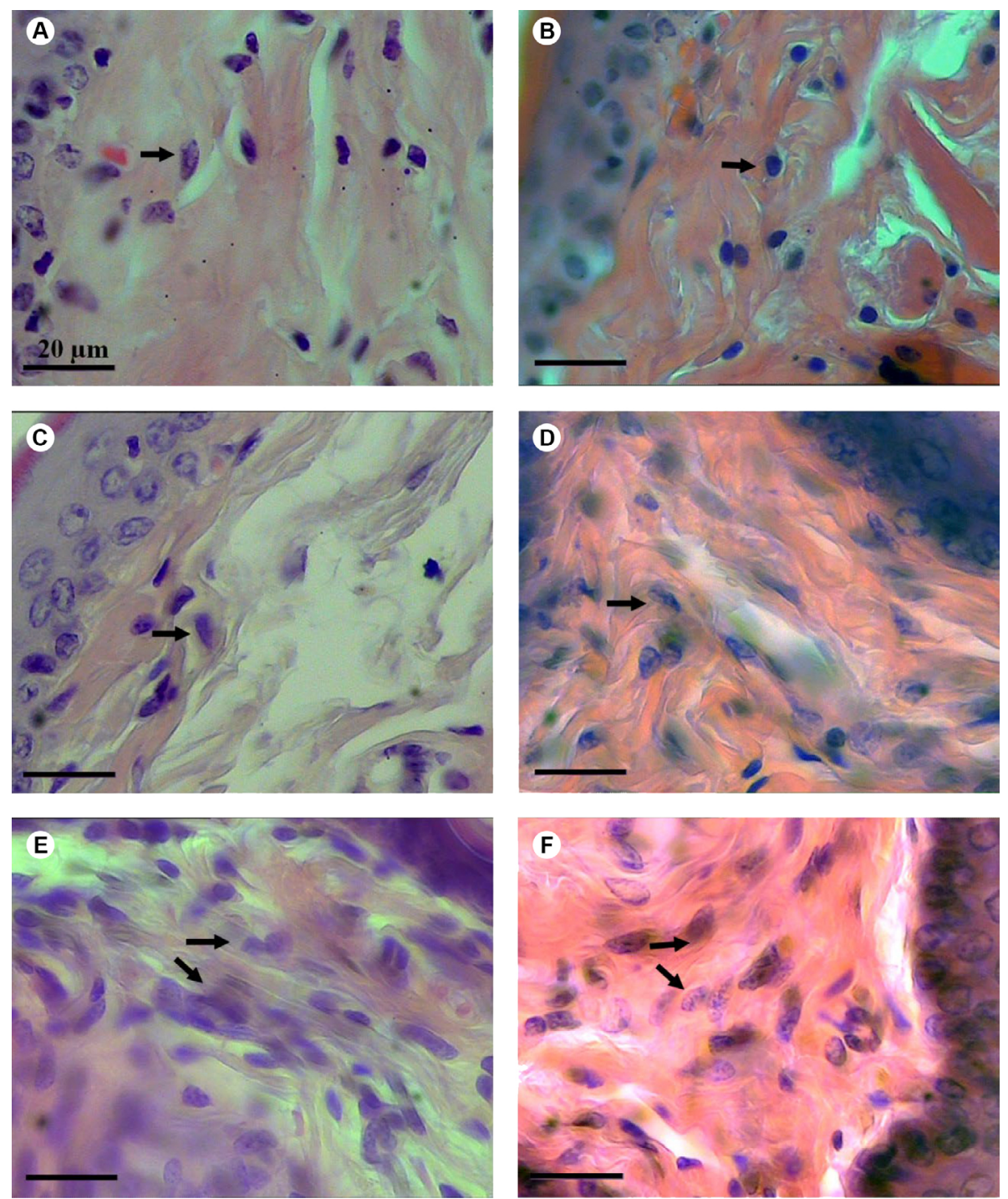

Figure 6. The micrograph of the fibroblast population in the oral mucosa of different groups. A: Control group on the 14th day; B: Control group on the 17th day; C: Gel-based group on the 14th day; D: Gel-based group on the 17th day; E: Eucalyptus-treated group on the 14th day; F: Eucalyptus-treated group on the 17th day. 
components in different diseases and clinical trials.

\section{Resumo}

A mucosite oral é uma complicação inflamatória comum em pacientes com câncer. Este estudo avaliou os marcadores histopatológicos, estereológicos e antioxidantes de Eucalyptus 2\% na mucosite oral induzida em hamsters dourados machos. Neste estudo em animais, a mucosite oral foi induzida em 30 hamsters golden masculinos por $5-\mathrm{FU}(60 \mathrm{mg} / \mathrm{kg})$ nos dias 0,5 e 10 do estudo. A bolsa da bochecha foi arranhada com uma agulha estéril uma vez ao dia nos dias 3 e 4 . Nos dias 14 a 17, os grupos de gel de eucalipto a $2 \%$ e curativos à base de gel foram tratados e comparados com um grupo controle. Foram avaliados os escores histopatológicos e estereológicos e o conteúdo de malondialdeído na bolsa, bem como as atividades de glutationa e mieloperoxidase no tecido da bolsa. Os escores histopatológicos de mucosite foram menores no grupo de gel de eucalipto a $2 \%$ do que os do gel e do grupo controle $(p<0,05)$. Além disso, um nivel mais baixo de malondialdeído e maiores atividades de mieloperoxidase e glutationa foram detectadas no grupo tratado com eucalipto em comparação aos grupos à base de gel e controle $(p<0,001)$. A espessura da mucosa e submucosa aumentou no grupo Eucalyptus. A densidade numérica do fibroblasto e a densidade do volume do colágeno aumentaram significativamente nos grupos tratados com eucalipto. Em conclusão, o uso do extrato hidroalcoólico de Eucalyptus pode estar associado a menor intensidade de mucosite oral, diminuição da concentração de malondialdeído, aumento da atividade de mieloperoxidase e glutationa, aumento do volume de mucosa e submucosa, aumento de fibroblastos e colágeno na mucosite oral induzida em hamsters dourados em consumo de 5 UF.

\section{ت Acknowledgements}

This research was supported by a grant from Shiraz University of Medical Sciences (Grant No. 1394-01-07-8794115).

\section{References}

1. Gupta N, Gupta R, Acharya AK, Patthi B, Goud V, Reddy S, et al. Changing Trends in oral cancer - a global scenario. Nepal J Epidemiol 2016;6:613619.

2. Rodríguez-Caballero $A$, Torres-Lagares $D$, Robles-Garcia M, Pachón-Ibáñez J, González-Padilla D, Gutiérrez-Pérez JL. Cancer treatment-induced oral mucositis: a critical review. Int J Oral Maxillofac Surg 2012;41:225-238.

3. D'Hondt Lionel, Lonchay Christophe, André Marc, Canon Jean-Luc .Oral mucositis induced by anticancer treatments: physiopathology and treatments. Ther Clin Risk Manag 2006;2:159-168.

4. Al-Sarraf M. Treatment of locally advanced head and neck cancer: historical and critical review. Cancer Control 2002;9:387-399.

5. Yarom N, Ariyawardana A, Hovan A, Barasch A, Jarvis V, Jensen S, et al. Systematic review of natural agents for the management of oral mucositis in cancer patients. Support Care Cancer 2013;21:3209-3221.

6. Bjordal J, Bensadoun R-J, Tunèr J, Frigo L, Gjerde K, Lopes-Martins R. A systematic review with meta-analysis of the effect of low-level laser therapy (LLLT) in cancer therapy-induced oral mucositis. Support Care Cancer 2011;19:1069-1077.

7. Tanideh N, Tavakoli P, Saghiri MA, Garcia-Godoy F, Amanat D, Tadbir $A A$, et al. Healing acceleration in hamsters of oral mucositis induced by 5-fluorouracil with topical Calendula officinalis. Oral Surg Oral Med Oral Pathol Oral Radiol 2013;115:332-338.

8. Tanideh N, Namazi F, AndishehTadbir A, Ebrahimi H, Koohi-Hosseinabadi 0. Comparative assessment of the therapeutic effects of the topical and systemic forms of Hypericumperforatum extract on induced oral mucositis in golden hamsters. Int J Oral Maxillofac Surg 2014;43:1286-1292.

9. Tanideh N,Davarmanesh M,Andisheh-Tadbir A,Ranjbar Z,MehriarP, Koohi-Hosseinabadi 0 . Healing acceleration of oral mucositis induced by 5-fluorouracil with Pistaciaatlantica (bene) essential oil in hamsters. J Oral Pathol Med 2017;46:725-730.

10. Koohi-Hosseinabadi O, Andisheh-Tadbir A, Bahadori P, Sepehrimanesh
M, Mardani M, Tanideh N. Comparison of the therapeutic effects of the dietary and topical forms of Zizyphusjujuba extract on oral mucositis induced by 5 -fluorouracil: a golden hamster model. J Clin Exp Dent 2015;7:e304

11. Sartorelli P, Marquioreto AD, Amaral-Baroli A, Lima MEL, Moreno PRH. Chemical composition and antimicrobial activity of the essential oils from two species of Eucalyptus. Phytother Res 2007;21:231-233.

12. Ghasemian $A$, Eslami M , Hasanvand $F_{1}$ Bozorgi $H_{1} A l$-abodie HR. Eucalyptus camaldulensis properties for use in the eradication of infections. Comp. Immunol. Microbiol. Infect. Dis 2019;65:234-237.

13. Chen J, Duan H, PanH, Yang X, Pana W. Two types of core/shell fibers based on carboxymethyl chitosan and Sodium carboxymethyl cellulose with self-assembled liposome for buccal delivery of carvedilol across TR146 cell culture and porcine buccal mucosa. Int J Biol Macromol 2019;128:700709.

14. Sonis ST, Tracey C, Shklar G, Jenson J, Florine D. An animal model for mucositis induced by cancer chemotherapy. Oral Surg Oral Med Oral Pathol 1990;69:437-443.

15. KhodakaramTafti A, Nazifi S, Rajaian H, Sepehrimanesh M, Poorbaghi SL, Mohtarami S. Pathological changes associated with experimental salinomycintoxicosis in sheep. Comp Clin Path 2008;17:255-8.

16. Lima V, Brito GA, Cunha FQ, Rebouças $C G$, Falcão BA, Augusto RF, et al. Effects of the tumour necrosis factor-alpha inhibitors pentoxifylline and thalidomide in short-term experimental oral mucositis in hamsters. Eur J Oral Sci 2005;113:210-217.

17. Priftis A, Soursou V, Makiou AS, Tekos F, Veskoukis AS, Tsantarliotou MP, et al. A lightly roasted coffee extract improves blood and tissue redox status in rats through enhancement of GSH biosynthesis. Food Chem Toxicol 2019;125:305-312.

18. Lata $H$, Ahuja GK, Narang AP, Walia L. Effect of immobilisation stress on lipid peroxidation and lipid profile in rabbits. Indian J ClinBiochem 2004;19:1-4.

19. Tanideh N, Zareh AA, Fani MM, Mardani M, Farrokhi F, TalatiA, et al. Evaluation of the effect of a topical gel form of pistaciaatlantica and trachyspermumammi on induced oral mucositis in male golden hamsters by bio-marker indices and stereological assessment. J Dent 2019;20:240248

20. Showraki N, Mardani M, Emamghoreishi M, Andishe-Tadbir A, Aram $A$, Mehriar $P$, et al. Topical olive leaf extract improves healing of oral mucositis in golden hamsters. J Dent 2016;17:334-342.

21. Mardani M, Afra SM, Tanideh N, Tadbir AA, Modarresi F, KoohiHosseinabadi 0 , et al. Hydroalcoholic extract of Carumcarvi L. in oral mucositis: a clinical trial in male golden hamsters. Oral Dis. 2016;22:39-45.

22. Koohi-Hosseinabadi O, Ranjbar Z, Sepehrimanesh M, AndisheTadbir A, Poorbaghi SL, Bahranifard $H$, et al. Biochemical, hematological, and pathological related healing effects of Elaeagnus angustifolia hydroalcoholic extract in 5-fluorouracil-induced oral mucositis in male golden hamster. Environ Sci Pollut Res 2017;24: :24447-24453.

23. Darshan $S$, Doreswamy R. Patented antiinflammatory plant drug development from traditional medicine. Phytother Res 2004;18:343-357.

24. Cermelli C, Fabio A, Fabio G, Quaglio P. Effect of eucalyptus essential oil on respiratory bacteria and viruses. Curr Microbiol 2008;56:89-92.

25. Hukkeri V, Karadi R, Akki K, Savadi R, Jaiprakash B, Kuppast I, et al. Wound healing property of Eucalyptus globulus L. leaf extract. Indian drugs 2002;39:481-483.

26. Choudhary G. Wound healing activity of the ethanol extract of Terminaliabellirica Roxb. fruits. Nat Prod Rad 2008;7:19-21.

27. Rousselle P, Braye F, Dayana G. Re-epithelialization of adult skin wounds: Cellular mechanisms and therapeutic strategies. Adv Drug Deliv Rev 2019;146:344-365.

28. Sugumar $\mathrm{S}$, Ghosh V, Nirmala MJ, Mukherjee $A$, Chandrasekaran N. Ultrasonic emulsification of eucalyptus oil nanoemulsion: antibacterial activity against Staphylococcus aureus and wound healing activity in Wistar rats. Ultrason Sonochem 2014;21:1044-1049.

Received September 3, 2019 Accepted January 23, 2020 